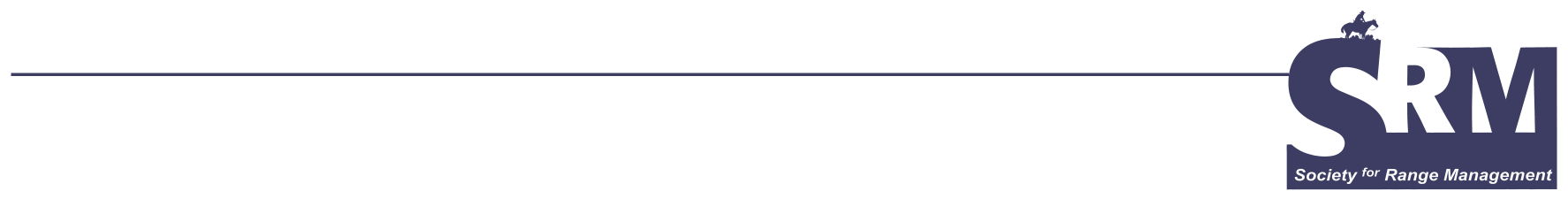

\title{
My Life as a Ranch Cowgirl
}

\section{By Shelby Frasier}

\section{My Goal Is to Beat My Mom!}

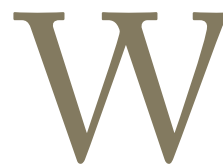

hat do ranching, rodeoing, and barrel racing have in common? From the early days, ranch work has involved riding horses to take care of the livestock on the rangelands. The early cowboys were very proud of their skills in roping cattle and riding horses. It was only a short time until the cowboys tested their skills in riding horses and roping against each other. This was the start of the professional rodeo we see today. With some exceptions, men were the primary contestants in rodeo events. Because most rodeo events are relatively dangerous, women were not allowed to compete. It is not hard to see that women also wanted to compete.

In 1948, 38 ranch women gathered in San Angelo, Texas, and organized a rodeo association just for women - the Girls Rodeo Association (GRA) was born. It was formed for 2 reasons: 1) to give women legitimate, honest opportunities to compete in all-girl rodeos and 2) to establish an alliance with the Rodeo Cowboy Association (RCA).

The GRA board members worked hard to persuade rodeo committees and producers to hold women's contests according to GRA rules. The Committees were given the option of choosing which event they would hold. Most of the Committee members picked barrel racing.

My family has pursued both ranching and professional rodeo since 1885 , when my great-great grandparents homesteaded in southwest Nebraska. My papa (Grandpa), C. O., a third-generation rancher, had a passion for training and raising quality quarter horses. His RCA card was number 110, which he kept current until his death in 2001. He dearly loved rodeoing. Due to the size of the ranching and farming operation he and his wife, Elaine, loved to operate, he

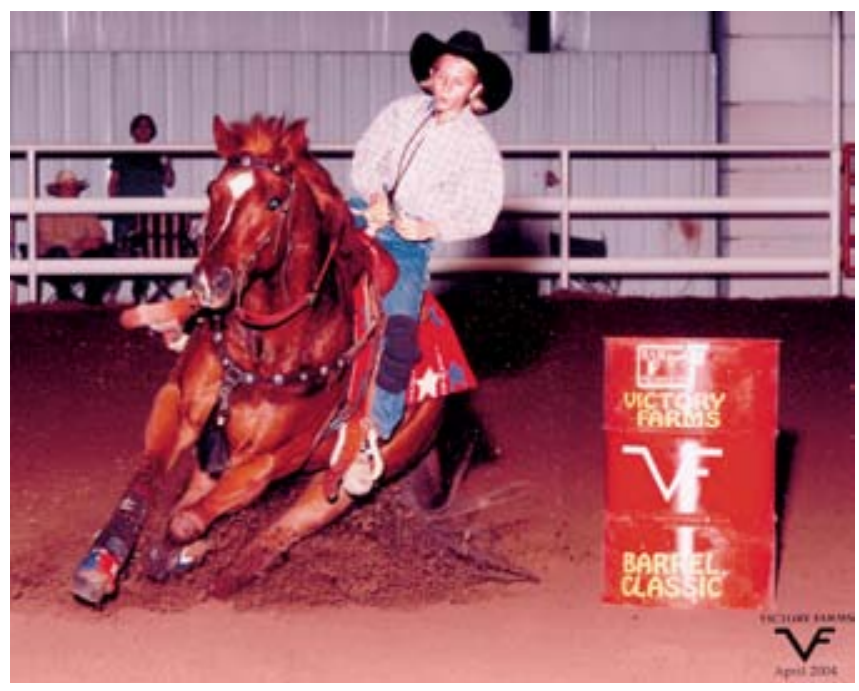

Shelby on "Red's on the Money" turning a barrel. (Editor's Note: There is an unusual aspect in the photo. See if you can find it. The answer is presented in a note at the end of Frasier's Philosophy, p. 65.) Photo courtesy of Victory Farms.

was not able to travel to compete in rodeos as much as he would have liked. However, in 1955, at the RCA Greeley Stampede rodeo, in Greeley, Colorado, he won his favorite event, calf roping, on a mare named Bald.

This makes me think of my mom, Deb.

In 1975, 20 years after papa won the calf roping at Greeley, my mom won the GRA barrel race, on a gelding, Bald's Breeze, a son of Bald. Slipping out to the barn to ride a couple horses papa raised, she developed her training skills on Bald's Breeze and a three-quarter brother, Bald's Folly. 
The mix was right, she tallied up 3 national high school, 2 intercollegiate, and 2 GRA National Finals Rodeo (NFRs) finals. She was the first and still is the only Nebraska ranch girl to win the national high school "All Around" title. She also won the national high-school barrel racing title on Bald's Breeze. And riding Bald's Folly, she still holds state high-school records on a single run and 3-run average in the pole bending in the state of Nebraska she set in 1971.

This brings me to my pony, Rusty, and me.

My mom bought Rusty for me at the sale in Cleburne, Texas, when I was 2 . He is my best friend, a little ornery, but maybe he got that from me. I spent lots of time riding him in the pasture with mom and whatever horse she was training at the time.

I started competing on him at a local roping club when I was 4 and, in 1999, we joined the NBHA (National Barrel Horse Association), a professional association for women and men with divisions for open (to all ages), youth (18 and under), and seniors (50 and over), who want to compete only in barrel racing. In 1999, my first year to compete in the NBHA, I qualified for the youth world show and have qualified every year since. In 2000 and 2001, I won the 3D and 4D divisions NBHA Year End District Championships on my pony competing against older kids on horses. I repeated those wins in 2002 and was 3D division NBHA District Champion on a horse named Seeker. In 2003, I won the 2D division NBHA Year End District Champion on Hopeshehungthemoon, a mare we raised and mom trained. In 2004, I took Rusty to the NBHA State Championship, and what do you know, he won the $4 \mathrm{D}$ division average to bring home the $4 \mathrm{D}$ NBHA State Championship buckle in the youth. We decided to take him to the NBHA World Show in Jackson, Mississippi. I was so excited to win 2 nd in the 1 st go round in the $4 \mathrm{D}$ division against 500 other horses and ponies. Of the ponies competing, he had the 2nd fastest time of the whole show. I received a World Qualifier Buckle. I was so proud.

We are going to compete one last time at the NBHA World Show this year. I will be 13 and Rusty 17. I will retire him after the NBHA World Show. A second horse I competed on at the 2004 NBHA World Show was Red's on the Money. I won the 2004 1D division NBHA Year End Championship on him. Making the transition from pony to horse hasn't been easy. But with quality horses like Red's on the Money and Hopeshehungthemoon, I've proven I can win.

I too have a passion to continue the family tradition of raising quality horses and riding in professional rodeos while living on a ranch in southwest Nebraska that has been in the Frasier name for 120 years.

I will beat my mom's records!

The author lives on a ranch outside of Benkelman in southwestern Nebraska. 